\title{
The mediating role of motivation for creative performance of cloud-based m-learning
}

\author{
Yu-shan Chang \\ National Taiwan Normal University
}

\begin{abstract}
The purpose of this study was to investigate the predictability of cloud-based m-learning for creative performance, and the mediating effect of motivation. The participants were 116 college students, who participated in the pre-test and post-test of a teaching experiment. The conclusions of this study are as follows: (1) cloud-based m-learning has a significant positive effect on the motivation of students, particularly on expectancy and affect; (2) cloud-based m-learning has a significant effect on the creative performance of students, particularly on elaboration and novelty; and (3) cloud-based m-learning exhibits predictability for creative performance and affects creative performance through using motivation as a mediator.
\end{abstract}

\section{Introduction}

In the era of a knowledge-based economy under the influence of globalisation and information, cultivating creativity is the top priority for excelling in the face of fierce competition (European Union, 2016; Gaspar \& Mabic, 2015; Janger, Schubert, Andries, Rammer, \& Hoskens, 2017). Considering the close connection between motivation and creativity (Amabile, 1996), enterprises and educational institutions have adopted various strategies to motivate individuals and ultimately promote creative performance (Gajda, 2016; Horng, Tsai, Yang, Liu, \& Hu, 2016). Amid the rapid development of cloud computing technologies, many countries have invested heavily in developing cloud-related industries and cloud-based education (National Science Foundation, 2016). For example, the United States Federal Government now spends approximately $8.5 \%$ of its budget on providing services, such as cloud computing (The White House, 2016). The Ministry of Education of Taiwan has pledged, in its Plan to Promote Cloud-Based Applications and Platform Services in Education, to spend US\$34 million over 5 years to build a national cloud-based service for schools (Ministry of Education, 2013). Cloud-based mobile learning (m-learning) can have multiple effects. In addition to motivating students, inspiring creativity, and inducing creative performance, cloud-based m-learning can have various qualitative and quantitative effects (Lin, Wenb, Jou, \& Wub, 2014).

Resources often employed to support cloud-based m-learning include cloud storage, professional knowledge databases, communication and interaction interfaces, and creative thinking software (Lin et al., 2014; Zurita, Baloian, \& Frez, 2014). In addition, cloud-based m-learning is particularly suitable for engaging in cooperative and constructivist learning (Chang \& Yu, 2015; Shorfuzzaman, Alelaiwi, Masud, Hassan, \& Hossain, 2015; Wang \& Jou, 2016). Therefore, this study explored the influence of cloud-based m-learning on the motivation and creative performance of learners. The results can contribute to building a theoretical framework regarding creativity and a designing framework for teaching practice.

\section{Literature review}

\section{Cloud-based m-learning}

Cloud-based m-learning is learning that occurs through use of cloud-based services and mobile devices (Alexandru, Nicolae, \& Loredana, 2013; García-Peñalvo, Johnson, Alves, Minović, \& Conde-González, 2014; Shorfuzzaman et al., 2014). The integration of three types of cloud computing platforms, infrastructure as a service (IaaS), platform as a service (PaaS) and software as a service (SaaS), enables learners to use handheld digital devices (e.g., cell phones, laptops, and tablets) to obtain, process, share, and store information seamlessly. Thus, learners can complete learning tasks by connecting to remote hardware equipment (Chao et al., 2015; Lin et al., 2014; Wang \& Jou, 2016).

The features of cloud-based m-learning include abundant resources (remote soft- and hardware), convenient access (anytime and anywhere), high interactivity (available for co-editing and sharing), 
individualisation, and self-regulated and self-directed learning (Lin et al., 2014; Wang \& Jou, 2016; Zurita et al., 2014). Creativity consists of four major components: (1) domain-relevant skills, (2) creativity-relevant processes, (3) task motivation, and (4) social environment (Amabile, 2012). These components can be fulfilled by using the features of and resources offered by cloud-based m-learning, which is beneficial for sharing professional knowledge, assisting in creative thinking (Karakaya \& Demirkan, 2015; Pektas \& Demirkan, 2011), building a creative culture within communities (Karakaya \& Demirkan, 2015; Muldner \& Burleson, 2015; Tsai, Horng, Liu, \& Hu, 2015), fostering a creative environment (Chang, Chien, Yu, Lin, \& Chen, 2016), and inspiring community members to develop creative motivations (Karakaya \& Demirkan, 2015). Subsequently, creative processes and results can be improved. As a project, we conducted a teaching experiment in a university to examine the effects of cloud-based m-learning on students' motivations and creative performance based on following two hypotheses:

H1. Cloud-based m-learning has a significant effect on motivation.

H2. Cloud-based m-learning has a significant effect on creative performance.

\section{Motivation}

Motivation is a vital component of creativity and represents a force that drives individuals to engage in learning, inspiring individual passion for creative learning and creation tasks (Amabile, 2012). Many scholars assert that intrinsic motivation is essential in generating creativity, because such motivation can increase positive influences, cognitive flexibility, risk-taking abilities, and persistence (Horng et al., 2016). Empirical studies have indicated that motivation is correlated with creative behaviour (Horng et al., 2016; Soroa, Balluerka, Hommel, \& Aritzeta, 2015). However, self-perceived creative behaviour does not necessarily equal creative performance. The ultimate goal of creativity is creative performance, namely, creative products (Gajda, 2016; Wallas, 1926). Therefore, the relationship between motivation and creative performance warrants further exploration (Gajda, 2016). After identifying the causal relationship between motivation and creative performance, we can improve creative performance by strengthening motivation.

Similar to approaches used in general investigations regarding the motivation that drives learning, scholars have employed intrinsic motivation as a principal factor when conducting motivation research on creative behaviour tendencies (Horng et al., 2016; Soroa et al., 2015). However, factors influencing creative performance are numerous, and both intrinsic and extrinsic motivation are vital (An, Song, \& Carr, 2016; Gajda, 2016). Hence, integrating these two types of motivation can comprehensively explain the driving forces of creative behaviour (Pintrich, 1989; Song, Kalet, \& Plass, 2016). The integrated motivational factors comprise three components, value, expectancy and affect (Pintrich, 1989), which can be measured using seven subscales (Erturan, Arslan, \& Demirhan, 2014; Smith \& Chen, 2015). In this study, we also used these three components as the basis for measuring motivation:

1. Value components: including intrinsic goal orientation, extrinsic goal orientation, and task value.

2. Expectancy components: including control of learning beliefs, self-efficacy for learning, and expectancy for success

3. Affective components: including test anxiety.

\section{Creative performance}

The ultimate purpose of creativity is the production of creative products (Wallas, 1926). The main characteristics of creative products are novelty and usefulness (Miron-Spektor \& Beenen, 2015), although the features might vary slightly according to professional field. For example, the features of creative products in the fields of engineering and visual design might differ (Honzíková \& Krotký, 2017; Miron-Spektor \& Beenen, 2015; Vuletic, Duffy, Hay, McTeague, \& Pidgeon, 2018).

Furthermore, the purpose of product creativity assessment can also vary. For example, novelty and usefulness are valued when assessing the creative performance of students (Chang et al., 2016); when the purpose is to improve and commercialise products, social aesthetic requirements and elaboration are emphasised (Lan \& Kaufman, 2013). Therefore, ratings are made based on novelty, resolution, and elaboration (Besemer, 1998), among other aspects (Miron-Spektor \& Beenen, 2015). By adopting a 
product design perspective, scholars have also subdivided product creativity into material, function, structure, and style factors (Chang \& Yu, 2015). This division provides guidance for designers or learners to engage in creative design.

In addition, assessment tools, such as the Creative Product Semantic Scale (CPSS) (Besemer, 1998), Student Product Assessment Form (SPAF) (Reis \& Renzulli, 1991), and Creative Idea Scale (CIS) (Chang $\& \mathrm{Yu}, 2015)$, are used to assess creativity by examining the overall work or ideas. Nevertheless, these tools are also based on the framework of novelty, resolution, and elaboration. Therefore, we employed this framework to assess the creative performance resulting from cloud-based learning.

H3. Motivation has a mediating effect on the predictability of cloud-based m-learning for creative performance.

\section{Method}

In order to investigate the predictability of cloud-based m-learning for creative performance and the mediating effect of motivation, a teaching experiment was conducted in a university. A non-equivalent group, pre-test post-test, quasi-experimental research design was used in this experiment. In the pre-test of motivation, we collected scores from the first design homework assignment as the pre-test scores before conducting the teaching experiment. Following 9 weeks of experimentation, the created images were rated. These scores served as the post-test scores in the post-test of motivation.

\section{Participants}

The participants, who were first-year students drawn from four classes at a national university in Taipei City, Taiwan, were randomly assigned to either the experimental group or the control group. The experimental and the control groups consisted of 59 and 57 students, respectively, giving a total of 116 participants. In accordance with the research ethics rules of Center for Research Ethics (CRE), National Taiwan Normal University and the research ethics rules of Ministry of Science and Technology, all participants were over 18 years old, were advised that taking part in the teaching experiment was entirely voluntary, and that their participation would have no consequences on their studies or grades.

All participants were anonymously identified by codes so that their personal identities were not disclosed. For each participant, we obtained an informed consent. The collected data did not pertain to an investigation on the individual characteristics of each student. The data was collected and processed anonymously and exclusively at group level, and subject to scientific communication (oral and written). A scientific report was provided at the end of the study to share the results. Further, there was no conflict of interest.

\section{Independent variable}

In this study, the independent variable was teaching strategy. Both groups adopted the analyse-create-make three-step design program (Archer, 1984). In addition, participants in the experimental group adopted the cloud-based m-learning strategy, where cloud-based applications (Facebook, Mindomo, and Cubie) were used to facilitate creative design. The creative task was to use the computer software Adobe Photoshop to design an innovative and elaborate digital image possessing communicative features. Figures 1 to 3 show the software employed and the participants' work. 


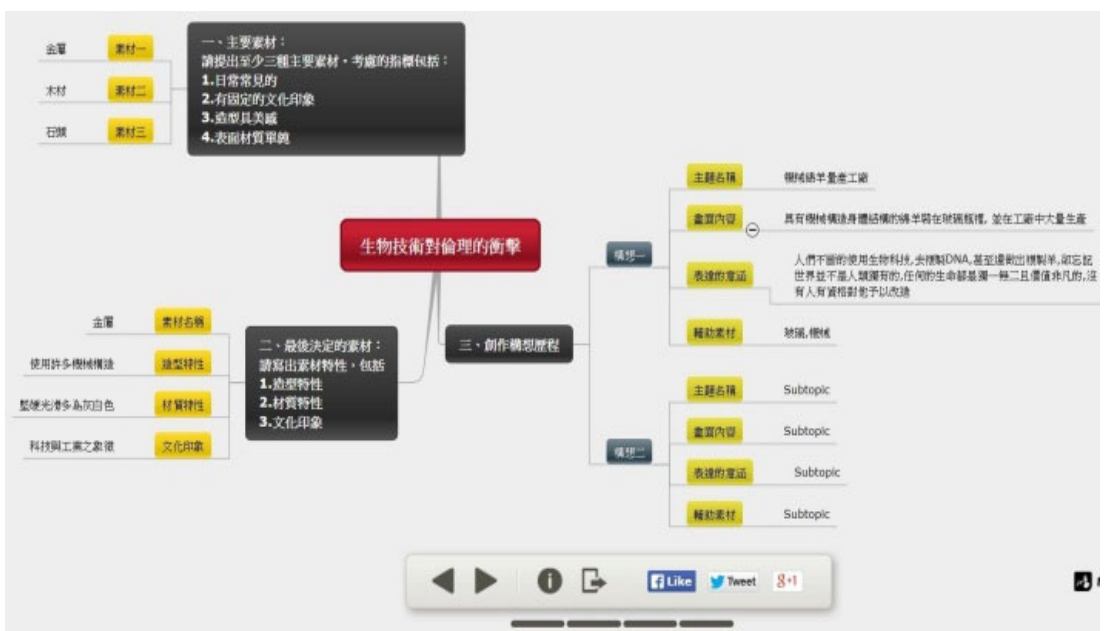

Figure 1. A mind map drawn using Mindomo

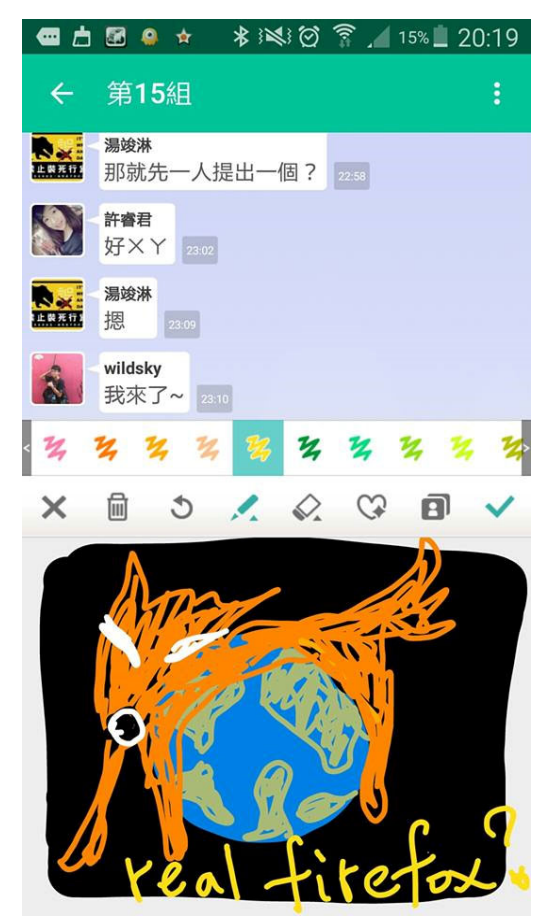

Figure 2. A screenshot of draft discussions that took place on Cubie

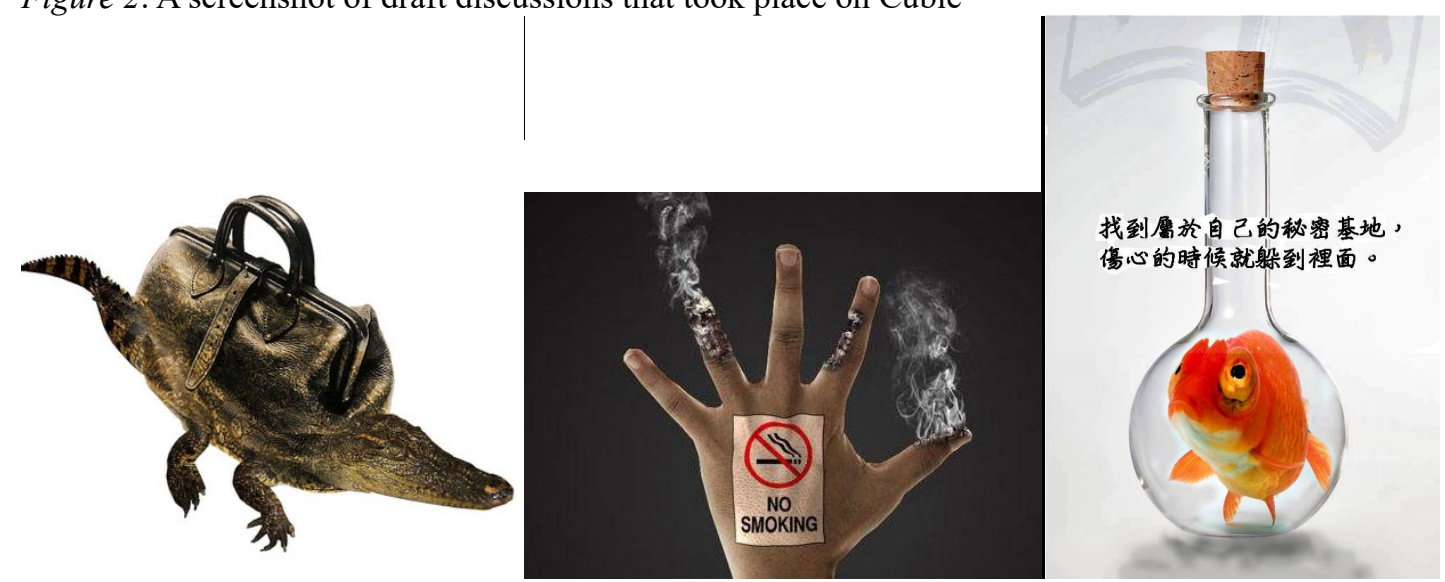

Figure 3. Digital images created by students 
Facebook was used as a main platform for uploading, downloading, and sharing web resources, learning materials, and works. Mindomo was used to produce mind maps, and it helped participant students address creative ideas and co-work cooperatively. Finally, Cubie was used to interact synchronously by texts, figures, and sketches. Additionally, students could propose and refine novel design ideas by relay sketching collaboratively on Cubie. The main teaching procedures are listed in Table 1.

Table 1

Main teaching procedures

\begin{tabular}{lll}
\hline Phase & Step & \multicolumn{1}{c}{ Experimental Group } \\
\hline Analysis & $\begin{array}{l}\text { Data } \\
\text { collection }\end{array}$ & $\begin{array}{l}\text { 1. } \\
\text { 2. Introduction of the learning task. } \\
\text { tools (Facebook, Mindomo, and } \\
\text { Cubie). }\end{array}$ \\
& & $\begin{array}{l}\text { 3. Formation of groups on Facebook. } \\
\text { 4. } \begin{array}{l}\text { Downloading of resources, such as } \\
\text { digital textbooks and image } \\
\text { materials from Facebook. }\end{array}\end{array}$
\end{tabular}

\begin{tabular}{ll}
\hline Creation Analysis & During class: \\
& 1. \\
& Teachers explained drawing \\
& techniques, media usage, creative \\
& techniques and the concept of \\
& design.
\end{tabular}

After class:

2. Students used Mindomo to organise and analyse creative concepts regarding materials, composition, modelling, colour and ideas, before drawing mind, maps.

3. Students used the Mindomo platform to create mind maps of their creative concepts by sharing and coediting the images with group members.

4. Students used Cubie software to draw out their creative concepts and discuss them with their group members.

Finalisation 1. Students finalised the creative concepts of their works after using Cubie for a group discussion.

2. Students used references downloaded from Facebook to search for suitable materials or conducted independent Internet searches and shared the results.

Making Development After class:

1. Students began to draw their design and used Cubie to upload drafts and report on progress.

2. Students used Cubie to revise and discuss their design and used the drawing function to communicate creative concepts.

3. Students made revisions based on the advice provided by group members until the design was completed.
1. Introduction of the learning task.

2. Teachers assign students to groups and make a group list.

3. Downloading of resources, such as digital textbooks and image materials.

During class:

1. Teachers explained drawing techniques, media usage, creative techniques and the concept of design.

After class:

2. Students organised and analysed creative concepts regarding materials, composition, modelling, colour, and ideas, before drawing mind maps.

3. Students shared and discussed their creative concepts in face-to-face discussions.

4. Students used paper and pen to write down their design concepts.

1. Students voted on their preferred design concept maps to finalise the design concepts.

2. Students independently searched for the materials and resources that they needed.

After class:

1. Students began to draw their design and discussed progress periodically.

2. Students revised their works repeatedly based on advice provided by group members until the design was completed. 


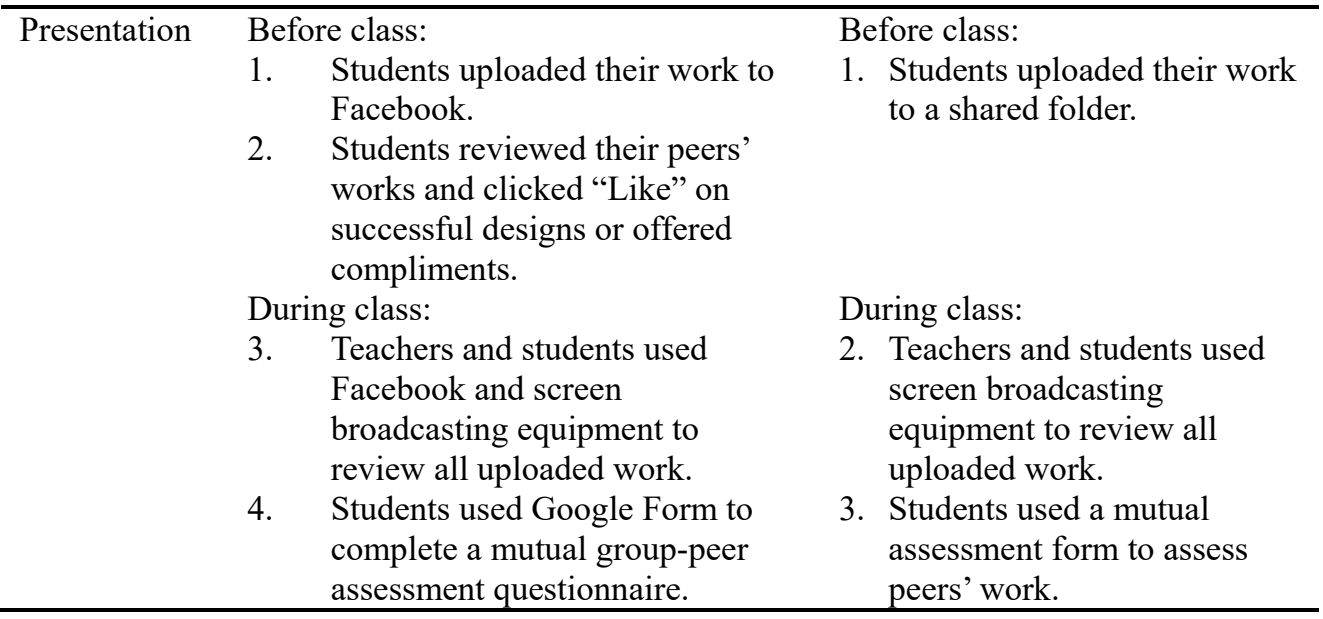

\section{Dependent variables}

In this study, we employed a revised version of the Motivated Strategies for Learning Questionnaire (MSLQ) (Pintrich, 1989; Wu \& Cheng, 1992) to determine the motivation of students for digital image creation learning. The revised MSLQ consisted of three components, value, expectancy and affect, totalling 33 items. The factor analysis explained $62.03 \%$ of the variance, had a Cronbach's $\alpha$ for internal consistency of between .71 and .91 , and showed satisfactory reliability and validity. Value component included three subscales: intrinsic goal orientation, extrinsic goal orientation, and task value. Expectancy component included three subscales: control of learning beliefs, self-efficacy for learning, and expectancy for success. Affect component included one subscale: test anxiety. Sample questions included:

- Mastering this learning content is important. (value component)

- I am sure I can perform excellent in this learning unit. (expectancy component)

- While facing exams, I always feel not well. (affect component)

For creative products, we used the creative indices for digital images developed by Chang (2002) as a basis, and included novelty (of materials and ideas), usefulness (communicability of meanings and liveliness of composition) and elaboration (of techniques) as the dimensions to be rated, adopting a 7-point Likert scale. The results of a pre-test showed the Cronbach' $\alpha$ for internal consistency of the rating mechanism was .88 ; the Kendall coefficient of concordance for inter-rater reliability was $W=.83$, indicating satisfactory reliability, greater than 0.70 (Amabile \& Pillemer, 2012; Karakaya \& Demirkan, 2015).

\section{Data analysis}

We conducted an analysis of covariance (ANCOVA) to explore the effects of cloud-based m-learning on motivation and creative performance, as well as the effects of motivation on creative performance. The results were used to test $\mathrm{H} 1$ and $\mathrm{H} 2$. In addition, regression analysis was performed to investigate whether learning motivation mediates the effect of cloud-based m-learning on creative performance, and whether cloud-based m-learning exhibits predictability for creative performance. The results were used to test H3.

\section{Research results}

\section{Cloud-based m-learning and motivation}

H1: Cloud-based m-learning has a significant effect on motivation.

The results of the multivariate ANCOVA showed a Wilk's Lambda of $.05(p<.001)$ and Eta squared of .95, thus indicating a significant effect (Murphy \& Myors, 2004). The results of the univariate ANCOVA revealed that cloud-based m-learning had a moderately significant effect on the expectancy exhibited by the two groups of participants $(F=8.61, p<.01$; Eta squared $=.07)$ and a significant effect on affect $(F=15.82, p<.01$; Eta squared $=.12)$. The results of a post hoc comparison showed that the 
experimental group exhibited motivation that yielded higher scores compared with the control group, for expectancy $(63.98>59.76)$ and affect $(24.74>21.08)$. Nevertheless, no significant difference existed in the value dimension $(F=2.51)$. The results are shown in Tables 2 and 3 .

\section{Cloud-based m-learning and creative performances}

H2: Cloud-based m-learning had a significant effect on creative performance.

The results of the multivariate ANCOVA showed a Wilk's Lambda of $.81(p<.001)$ and Eta squared of .19, indicating a significant effect (Murphy \& Myors, 2004). The results of the univariate ANCOVA of the creative performance items showed that both groups exhibited creative performance indicating significant effects on elaboration $(F=11.12, p<.01$; Eta squared $=.09)$ and novelty $(F=16.98, p<.01$; Eta squared $=.13)$. By contrast, we determined a moderately significant effect on usefulness $(F=4.11, p$ $<.05$; Eta squared $=.03$ ). The results of a post hoc comparison showed that the experimental group had higher scores compared with the control group for elaboration $(6.12>4.58)$, novelty $(9.47>8.19)$ and usefulness $(10.29>8.26)$. The results are shown in Tables 2 and 3 .

Table 2

Descriptive statistics for motivation and creative performance

\begin{tabular}{|c|c|c|c|c|c|c|c|c|c|c|}
\hline \multirow{3}{*}{ Item } & \multicolumn{5}{|c|}{$\begin{array}{l}\text { Control Group } \\
(n=57)\end{array}$} & \multicolumn{5}{|c|}{$\begin{array}{l}\text { Experimental Group } \\
(n=59)\end{array}$} \\
\hline & \multicolumn{2}{|c|}{ Pre-test } & \multicolumn{2}{|c|}{ Post-test } & \multirow[b]{2}{*}{$\operatorname{Adj} M$} & \multicolumn{2}{|c|}{ Pre-test } & \multicolumn{3}{|c|}{ Post-test } \\
\hline & $M$ & $S D$ & $M$ & $S D$ & & $M$ & $S D$ & $M$ & $S D$ & $\operatorname{Adj} M$ \\
\hline Motivation & 143.98 & 18.17 & 155.34 & 17.92 & - & 145.69 & 2331 & 165.94 & 21.77 & - \\
\hline 1. Value & 66.86 & 11.78 & 73.15 & 8.82 & 74.21 & 67.92 & 13.07 & 76.08 & 11.04 & 75.64 \\
\hline 2. Expectancy & 57.15 & 8.60 & 59.98 & 7.89 & 59.76 & 57.12 & 10.83 & 63.52 & 8.88 & 63.98 \\
\hline 3. Affect & 21.03 & 4.20 & 22.20 & 3.47 & 21.08 & 20.01 & 3.80 & 24.34 & 5.00 & 24.74 \\
\hline $\begin{array}{l}\text { Creative } \\
\text { performance }\end{array}$ & 18.59 & 4.19 & 20.17 & 6.53 & - & 19.06 & 5.92 & 25.62 & 5.68 & - \\
\hline 1. Elaboration & 4.05 & 1.25 & 4.62 & 1.70 & 4.58 & 4.01 & 1.43 & 5.71 & 1.43 & 6.12 \\
\hline 2. Novelty & 720 & 1.85 & 825 & 2.30 & 8.19 & 7.18 & 2.21 & 9.15 & 2.31 & 9.47 \\
\hline 3. Usefulness & 7.34 & 1.89 & 8.32 & 2.91 & 826 & 7.49 & 2.30 & 10.07 & 2.57 & 10.29 \\
\hline
\end{tabular}

Table 3

ANCOVA of motivation and creative performance

\begin{tabular}{|c|c|c|c|c|c|c|c|c|}
\hline & Item & Source & $\begin{array}{l}\text { Sum of } \\
\text { Squares }\end{array}$ & $d f$ & $\begin{array}{l}\text { Mean } \\
\text { square }\end{array}$ & $F$ & $p$ & Eta sq \\
\hline \multirow[t]{6}{*}{ Motivation } & \multirow[t]{2}{*}{ Value } & $\begin{array}{c}\text { Experimental } \\
\text { treatment }\end{array}$ & 253.57 & 1 & 253.57 & 2.51 & .12 & .02 \\
\hline & & Error & 12146.30 & 115 & & & & \\
\hline & \multirow[t]{2}{*}{ Expectancy } & $\begin{array}{c}\text { Experimental } \\
\text { treatment }\end{array}$ & 603.60 & 1 & 603.60 & $8.61 * *$ & .01 & .07 \\
\hline & & Error & 8410.20 & 115 & & & & \\
\hline & \multirow[t]{2}{*}{ Affect } & $\begin{array}{c}\text { Experimental } \\
\text { treatment }\end{array}$ & 298.26 & 1 & 298.26 & $15.82 * *$ & .00 & .12 \\
\hline & & Error & 2262.05 & 115 & & & & \\
\hline \multirow[t]{6}{*}{$\begin{array}{c}\text { Creative } \\
\text { performance }\end{array}$} & \multirow[t]{2}{*}{ Elaboration } & $\begin{array}{c}\text { Experimental } \\
\text { treatment }\end{array}$ & 25.35 & 1 & 25.35 & $11.12 * *$ & .00 & .09 \\
\hline & & Error & 273.51 & 115 & & & & \\
\hline & \multirow[t]{2}{*}{ Novelty } & $\begin{array}{c}\text { Experimental } \\
\text { treatment }\end{array}$ & 85.24 & 1 & 85.24 & $16.98^{* *}$ & .00 & .13 \\
\hline & & Error & 602.27 & 115 & & & & \\
\hline & \multirow[t]{2}{*}{ Usefulness } & $\begin{array}{c}\text { Experimental } \\
\text { treatment }\end{array}$ & 28.35 & 1 & 28.35 & $4.11 *$ & .04 & .03 \\
\hline & & Error & 827.06 & 115 & & & & \\
\hline
\end{tabular}

${ }^{* *} p<0.1,{ }^{*} p<.05$. 


\title{
Predictability of cloud-based m-learning for creative performance with motivation as a mediating factor
}

\begin{abstract}
H3: Motivation has a mediating effect on the predictability of cloud-based m-learning for creative performance.

Using teaching strategy as the independent variable $\mathrm{X}$, creative result as the dependent variable $\mathrm{Y}$ and motivation as the mediator $\mathrm{M}$, we conducted three simple regressions and one multiple hierarchical regression. The findings showed that teaching strategy could predict creative performance $\left(\mathrm{b}_{\mathrm{c}}=.51, R^{2}\right.$ $=.26, p=.000<.01)$ by explaining $26 \%$ variance. Teaching strategy could predict motivation $\left(\mathrm{b}_{\mathrm{a}}=.46, R^{2}\right.$ $=.21, p=.000<.01)$ by explaining $21 \%$ variance. Motivation could predict creative performance $\left(\mathrm{b}_{\mathrm{b}}=.62\right.$, $\left.R^{2}=.38, p=.000<.01\right)$ by explaining $38 \%$ variance. The results satisfied the three conditions of a mediating effect, as identified by Baron and Kenny (1986). Teaching strategy could predict motivation indirectly $\left(\mathrm{bc}=.47, R^{2}=.22, p=.000<.01\right)$ by explaining $22 \%$ variance. The results of a multiple hierarchical regression showed the total effect of teaching strategy and motivation on creative results $(.51$ $+.46 \times .62=.79)\left(\right.$ Path $\mathrm{c}+$ Path $\left.\mathrm{c}^{\prime}\right)$. The explained variance was $65.7 \%$, as shown in Figure 4.
\end{abstract}

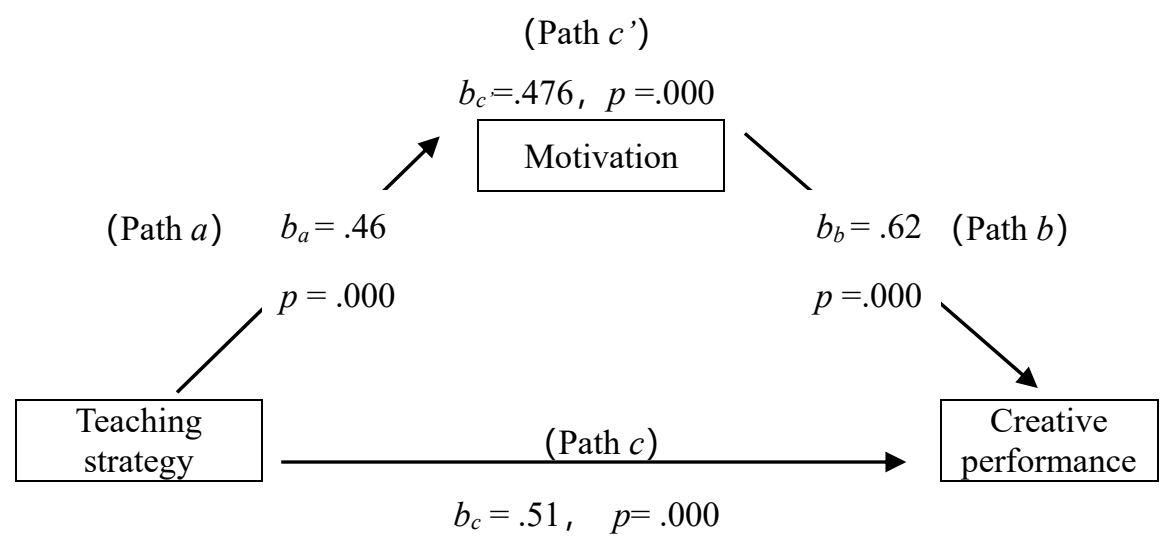

Figure 4. Paths of the effects of teaching strategy and motivation on creative performance

\section{Discussion}

\section{Cloud-based m-learning and motivation}

The results of this study showed cloud-based m-learning had a significant positive effect on the motivation exhibited by students. This finding is consistent with that of Jou and Wang (2013). In particular, the effects on expectancy and affect were significant. During the cloud-based m-learning conducted in this study, learners used the creative thinking software Mindomo to motivate creativity before using social networking software (Facebook and Cubie) to coedit and share the creative results. Therefore, learners could interact and cooperate with each other at any time, and observed the process of, and works created by, themselves and others. Therefore, learners felt less anxious and more comfortable and had an enhanced sense of self-worth, which is a positive feeling. Immediate appearance, participation, and response can strengthen motivation and reduce alienation, which were problems in previous types of online learning.

Cloud-based m-learning provides access to more relevant information (regarding methods and examples of creation) and resources (e.g., image materials), which enables learners to become more confident in completing the tasks (Cybulski, Keller, Nguyen, \& Saundage, 2015). In addition, the high interactivity and cooperative creation that occur during the process of learning resulted in stronger group support and encouragement (Cybulski et al., 2015), thus motivating learners to continue participating (Lin et al., 2014). High expectancy and positive affect resulted in stronger motivation for creative activity and learning (Hadwin \& Järvelä, 2011; Hew \& Kadir, 2016; Nouri, Erez, Lee, Liang, Bannister, \& Chiu, 2015).

Hence, the features of cloud-based m-learning, which include remote resource integration, high interactivity, coediting, and resource sharing, can effectively enhance the motivation of learners. Because the learning content presented to the two groups was controlled, the value that both groups of participants 
placed on learning contents and processes did not differ significantly. In future research, researchers could combine the value of learning content and learning processes with cloud computing. For example, more suitable applications could be adopted, or the importance of the capacity of cloud computing highlighted. In this way, the value dimension of motivation can be enhanced.

\section{Cloud-based m-learning and creative performance}

The results of this study showed that cloud-based m-learning had a significant effect on the creative performance of students, particularly on elaboration and novelty. The influence on the usefulness dimension was moderate, because achieving usefulness requires professional know-how pertaining to design and sufficient basic training. The participants used creative thinking software (Mindomo) to jointly draw mind maps, and social networking software (Facebook and Cubie) to engage in real-time creative interactions and, ultimately, to generate new ideas or improve existing ones. Thus, the creative performance of the students improved. A real-time, free, equal, and criticism-free participation environment is a special feature of the cloud-based m-learning environment, which is beneficial for improving creative performance (Chang \& Yu, 2015; Karakaya \& Demirkan, 2015; Vuletic et al., 2018).

The knowledge-sharing, and constant discussion and revision, made possible by the cloud environment can improve the usefulness of creative performance (Chang \& Yu, 2015; Miron-Spektor \& Beenen, 2015). This finding was confirmed in the present study. Additionally, cloud-based m-learning can be conducted using updated applications (Chao et al., 2015). Choosing novel applications based on learners' creative cognition and thinking habits, as well as the features that characterise creation in various professions (e.g., product design, architectural design, and fashion design), can enhance creative performance significantly. Furthermore, employing remote physical machines and resources in cloud-based m-learning also greatly influences creative performance (Chao et al., 2015). For example, design products can be produced using cloud-based 3D printing and laser cutting.

\section{The predictability of cloud-based m-learning for creative performance under the mediating effect of motivation}

Under the mediating effect of motivation, the predictability of cloud-based m-learning for creative performance exhibited a total effect size of 0.79. Empirical research has also shown that adopting appropriate teaching strategies can effectively improve learners' creativity and motivation (Hong, O'Neil, $\&$ Peng, 2016). According to relevant literature, motivation is necessary for creativity and can be used to predict creative behaviour (Amabile, 2012; Gajda, 2016; Hennessey, 2015; Honzíková \& Krotký, 2017). However, the predictability of motivation for creative performance is not as strong (An et al., 2016). When individuals attempt to predict creative behaviour, the influence of intrinsic motivation (resulting from interest, enjoyment, satisfaction, and the challenge presented by the work itself) outweighs that of extrinsic motivation, although both types of motivation act as mediators (Amabile, 2012). When teachers and researchers use motivation to predict creative performance, they might need to use field knowledge as a mediator (An et al., 2016) or measure the influence of extrinsic motivation (e.g., goal-oriented incentives; An et al., 2016; Soroa et al., 2015). Hence, cloud-based m-learning has significant predictability for learners' creative performance under the mediating effect of motivation. In addition, intrinsic and extrinsic motivations play different and pertinent roles.

\section{Conclusion and recommendations}

This study investigated the predictability of cloud-based m-learning for creative performance and the mediating effect of motivation. In summary, the project can conclude that:

- Cloud-based m-learning has a significant positive effect on the motivation of students, with particularly significant effects on expectancy and affect. Teachers should choose appropriate applications with professional features to enable students to understand the value of learning content and learning processes.

- Cloud-based m-learning has a significant effect on the creative performance of students, with particularly significant effects on elaboration and novelty. Teachers can use professional software and cloud-based hardware to improve the usefulness of creative works. 
- Cloud-based m-learning has predictability for creative performance and can influence such performance via the mediating factor of motivation. During instructional design, teachers should ensure that the tasks are not excessively difficult. During the process of teaching, teachers can induce intrinsic motivation at the creativity stimulation stage, thus ultimately enhancing creativity. At the product creation stage, teachers can use extrinsic motivation to encourage higher-quality work. Additionally, the "Like" function on social networking software, and the offering of compliments, can engender stronger intrinsic motivation in students.

The results of this study confirmed the effect of cloud-based m-learning in terms of fostering creativity in students. This approach should be widely adopted in schools. Combining the theories of creativity and motivation, and developing software that can be used for teaching at schools, are necessary for promoting creative, cloud-based mobile teaching in the future. Additionally, the learning task used in this study had a digital image design, which differs from actual product design and industrial design in terms of both materials and tools. Future studies should focus on different professional areas to examine the effects of various teaching models. In conclusion, our results could be used to enhance the effect of cloud-based m-learning on the creative performance of students engaged in various fields of study.

\section{Acknowledgement}

We would like to thank I-Fan Tsai for helping in teaching experiment. We would like to thank the Ministry of Science and Technology (Taiwan) for financial support of this research under contract numbers NSC 106-2514-S-003 -005 and NSC 105-2511-S-003 -008 -MY2

\section{References}

Alexandru, B., Nicolae, T., \& Loredana, M. (2013). Cloud-based mobile learning. Informatica Economica, 17(2), 27-40. https://doi.org/10.12948/issn14531305/17.2.2013.03

Amabile, T. (1996). The motivation for creativity in organizations. Boston, MA: Harvard Business School.

Amabile, T. (2012). Componential theory of creativity. Retrieved from http://www.hbs.edu/faculty/Publication\%20Files/12-096.pdfAmabile, T., \& Pillemer, J. (2012). Perspectives on the social psychology of creativity. The Journal of Creative Behavior, 46(1), 3-15. https://doi.org/10.1002/jocb.001

An, D., Song, Y., \& Carr, M. (2016). A comparison of two models of creativity: Divergent thinking and creative expert performance. Personality and Individual Differences, 90, 78-84. https://doi.org/10.1016/j.paid.2015.10.040

Archer, L.B. (1984). Systematic method for designers. In N. Cross (Ed.) Developments in design methodology (pp. 57-82). Chichester: John Wiley \& Sons.

Baron, R., \& Kenny, D. (1986). The moderator-mediator variable distinction in social psychological research: Conceptual, strategy, and statistical considerations. Journal of Personality and Social Psychology, 51(6), 1173-1182.

Besemer, S. P. (1998). Creative product analysis matrix: Testing the model structure and a comparison among products - three novel chairs. Creativity Research Journal, 11(4), 333-346. https://doi.org/10.1207/s15326934crj1104_7

Chang, Y. S. (2002, May). Indicators of creative digital images. Paper presented at the Conference on General Education and Arts Education, Minghsin University of Science and Technology

Chang, Y. S., Chien, Y. H., Yu, K. C., Lin, H. C., \& Chen, M. Y. C. (2016). Students' innovative environmental perceptions and creative performances in cloud-based m-learning. Computers in Human Behavior, 63, 988-994. https://doi.org/10.1016/j.chb.2016.06.032

Chang, Y. S., \& Yu, K. C. (2015). The relationship between perceptions of an innovative environment and creative performance in an online synchronous environment. Computers in Human Behavior, 49, 38-43. https://doi.org/10.1016/j.chb.2015.02.040Chao, K. M., James, A. E., Nanos, A. G., Chen, J. H., Stan, S. D., Muntean, I., ... van Capelle, J. (2015). Cloud e-learning for mechatronics: CLEM. Future Generation Computer Systems, 48, 46-59. https://doi.org/10.1016/j.future.2014.10.033

Cybulski, J. L., Keller, S., Nguyen, L., \& Saundage, D. (2015). Creative problem solving in digital space using visual analytics. Computers in Human Behavior, 42, 20-35. 
https://doi.org/10.1016/j.chb.2013.10.061

Erturan, G., Arslan, Y., \& Demirhan, G. (2014). A validity and reliability study of the motivated strategies for learning questionnaire. Educational Sciences: Theory \& Practice, 14(3), 829-833. https://files.eric.ed.gov/fulltext/EJ1034112.pdf

European Union (2016). EU youth report. Retrieved from http://ec.europa.eu/youth/library/reports/youth-report-2015_en.pdf

Gajda, A. (2016). The relationship between school achievement and creativity at different educational stages. Thinking Skills and Creativity, 19, 246-259. https://doi.org/10.1016/j.tsc.2015.12.004

García-Peñalvo, F. J., Johnson, M., Alves, G. R., Minović, M., \& Conde-González, M. Á. (2014). Informal learning recognition through a cloud ecosystem. Future Generation Computer Systems, 32, 282-294. https://doi.org/10.1016/j.future.2013.08.004

Gaspar, D., \& Mabic, M. (2015). Creativity in higher education. Universal Journal of Educational Research, 3(9), 598-605. https://doi.org/10.13189/ujer.2015.030903

Hadwin, A. \& Järvelä, S. (2011). Introduction to a special issue on social aspects of self-regulated learning: Where social and self meet in the strategic regulation of learning. Teachers College Record, $113(2), 235-239$.

Hennessey, B. A. (2015). Creative behavior, motivation, environment and culture: The building of a systems model. The Journal of Creative Behavior, 49(3), 194-210. https://doi.org/10.1002/jocb.97

Hew, T. S., \& Kadir, S. L. S. A. (2016). Predicting the acceptance of cloud-based virtual learning environment: The roles of self determination and channel expansion theory. Telematics and Informatics, 33, 990-1013. https://doi.org/10.1016/j.tele.2016.01.004

Hong, E., O’Neil, H., \& Peng, Y. (2016). Effects of explicit instructions, metacognition, and motivation on creative performance. Creativity Research Journal, 28(1), 33-45. https://doi.org/10.1080/10400419.2016.1125252

Honzíková, A., \& Krotký, J. (2017). Correlation between psychomotor skills and creativity among secondary school students and future teachers. Edukacja - Technika - Informatyka nr, 2(20), 93-101. https://doi.org/10.15584/eti.2017.2.11

Horng, J. S., Tsai, C. Y., Yang, T. C., Liu, C. H., \& Hu, D.C. (2016). Exploring the relationship between proactive personality, work environment and employee creativity among tourism and hospitality employees. International Journal of Hospitality Management, 54, 25-34. https://doi.org/10.1016/j.ijhm.2016.01.004

Janger, J., Schubert, T., Andries, P., Rammer, C., \& Hoskens, M. (2017). The EU 2020 innovation indicator: A step forward in measuring innovation outputs and outcomes? Research Policy, 46(1), 30-42. https://doi.org/10.1016/j.respol.2016.10.001

Jou, M., \& Wang, J. J. (2013). Observations of achievement and motivation in using cloud computing driven CAD: Comparison of college students with high school and vocational high school backgrounds. Computers in Human Behavior, 29(2), 364-369. https://doi.org/10.1016/j.chb.2012.08.001

Karakaya, A. F., \& Demirkan, H. (2015). Collaborative digital environments to enhance the creativity of designers. Computers in Human Behavior, 42, 176-186.https://doi.org/10.1016/j.chb.2014.03.029

Lan, L., \& Kaufman, J. C. (2013). American and Chinese similarities and differences in defining and valuing creative products. The Journal of Creative Behavior, 46(4), 285-306. https://doi.org/10.1002/jocb.19

Lin, Y. T., Wenb, M. L., Jou, M., \& Wub, D. W. (2014). A cloud-based learning environment for developing student reflection abilities. Computers in Human Behavior, 32, 244-252. https://doi.org/10.1016/j.chb.2013.12.014

Ministry of Education (2013). Plan to promote cloud-based applications and platform services in education (2012-2017). Retrieved from http://www.ey.gov.tw/Upload/RelFile/27/704682/8d02f61f-8086-4169-825d-d8d5f42b3aa8.pdf

Miron-Spektor, E., \& Beenen, G. (2015). Motivating creativity: The effects of sequential and simultaneous learning and performance achievement goals on product novelty and usefulness. Organizational Behavior and Human Decision Processes, 127, 53-65. https://doi.org/10.1016/j.obhdp.2015.01.001

Muldner, K., \& Burleson, W. (2015). Utilizing sensor data to model students' creativity in a digital environment. Computers in Human Behavior, 42, 127-137. https://doi.org/10.1016/j.chb.2013.10.060

Murphy, K. R., \& Myors, B. (2004). Statistical power analysis: A simple and general model for traditional and modern hypothesis tests (2nd ed.). Mahwah NJ: Lawrence Erlbaum.

National Science Foundation (2016). Enabling a new future for cloud computing. Retrieved from 
http://www.nsf.gov/news/news summ.jsp?cntn id $=132377$

Nouri, R., Erez, M., Lee, C., Liang, J., Bannister, B. D., \& Chiu, W. (2015). Social context: Key to understanding culture's effects on creativity. Journal of Organizational Behavior, 36(7), 899-918. https://doi.org/10.1002/job.1923

Pektas, S. T., \& Demirkan, H. (2011). Experiences with Moodle as a communication tool for design teamwork: A users' perspective. METU Journal of the Faculty of Architecture, 28(2), 227-241. http://jfa.arch.metu.edu.tr/archive/0258-5316/2011/cilt28/sayi_2/227-241.pdf

Pintrich, P. R. (1989). The dynamic interplay of student motivation and cognition in the college classroom. In C. Ames, \& M. Maehr (Eds.), Advances in motivation and achievement: Motivation enhancing environments (Vol. 6, pp. 117-160). Greenwich, CT: JAI Press

Reis, S. M., \& Renzulli, J. S. (1991). The assessment of creative products in programs for gifted and talented students. Gifted Child Quarterly, 35(3), 128-134. http://journals.sagepub.com/doi/pdf/10.1177/001698629103500304

Shorfuzzaman, M., Alelaiwi, A., Masud, M., Hassan, M. M., \& Hossain, M. S. (2015). Usability of a cloud-based collaborative learning framework to improve learners' experience. Computers in Human Behavior, 51, 967-976. https://doi.org/10.1016/j.chb.2014.10.002

Smith, S. M., \& Chen, C. (2015). MSLQ: Instrument validation of motivation and learning strategies for acquiring computer software application skills. Issues in Information Systems, 16(3), 108-118. http://www.iacis.org/iis/2015/3 iis_2015_108-118.pdf

Song, H. S., Kalet, A. L., \& Plass, J. L. (2016). Interplay of prior knowledge, self-regulation and motivation in complex multimedia learning environments. Journal of Computer Assisted Learning, 32(1), 31-50. https://doi.org/10.1111/jcal.12117

Soroa, G., Balluerka, N., Hommel, B., \& Aritzeta, A. (2015). Assessing interactions between cognition, emotion, and motivation in creativity: The construction and validation of EDICOS. Thinking Skills and Creativity, 17, 45-58. https://doi.org/10.1016/j.tsc.2015.05.002

The White House (2016). The budget for fiscal year 2016. Retrieved from https://www.whitehouse.gov/sites/default/files/omb/budget/fy2016/assets/future.pdf

Tsai, C., Horng, J., Liu, C., \& Hu, D. (2015). Work environment and atmosphere: The role of organizational support in the creativity performance of tourism and hospitality organizations. International Journal of Hospitality Management, 46, 26-35. https://doi.org/10.1016/j.ijhm.2015.01.009

Vuletic, T., Duffy, A., Hay, L., McTeague, C., \& Pidgeon, L. (2018). The challenges in computer supported conceptual engineering design. Computers in Industry, 95, 22-37. https://doi.org/10.1016/j.compind.2017.11.003

Wallas, G. (1926). The art of thought. New York, NY: Harcourt Brace.

Wang, J., \& Jou, M. (2016). Qualitative investigation on the views of inquiry teaching based upon the cloud learning environment of high school physics teachers from Beijing, Taipei, and Chicago. Computers in Human Behavior, 60, 212-222. https://doi.org/10.1016/j.chb.2016.02.003

$\mathrm{Wu}$, J. \& Cheng, B. (1992). Revision of the motivated strategies for learning questionnaire. Psychological Testing, 39, 59-78.

Zurita, G., Baloian, N., \& Frez, J. (2014). Using the cloud to develop applications supporting geo-collaborative situated learning. Future Generation Computer Systems, 34, 124-137.

https://doi.org/10.1016/j.future.2013.10.007

Corresponding author: Yu-shan Chang, sam168@ntnu.edu.tw

Australasian Journal of Educational Technology (C) 2019.

Please cite as: Chang, Y. S. (2019). The mediating role of motivation for creative performance of cloud-based m-learning. Australasian Journal of Educational Technology, 35(4), 34-45. https://doi.org/10.14742/ajet.4418 